\title{
Assessment of Impact of Different Preservation Methods on the Nutritional Composition of Catfish Heteropneustes
}

\section{fossilis}

\author{
Samim AR ${ }^{1}$, Vaseem $H^{1 *}$ and Kumari $\mathbf{P}^{2}$ \\ ${ }^{1}$ Department of Zoology, Aligarh Muslim University, India \\ 2D S college, Bhimrao Ambedkar University, India
}

*Corresponding author: Huma Vaseem, Assistant Professor, Department of Zoology, Aligarh Muslim University, Aligarh, India, Email: vaseem18huma@gmail.com

\section{Research Article \\ Volume 2 Issue 6}

Received Date: November 30, 2019

Published Date: December 12, 2019

DOI: $10.23880 /$ izab- 16000190

\section{Abstract}

The present study is designed to investigate the effect of different preservation methods on the proximal composition of Heteropneustes fossilis. Fish were subjected to freezing, oven drying and sun drying for seven days. Various nutritive components like protein, lipid, moisture, ash, glucose and triglycerides were investigated in all preserved as well as fresh fishes. Alteration in all these components were observed after preservation when compare to the fresh fishes. Protein content decreased in all preserved fish in comparison to fresh fish. Least amount of fat was present in fresh fish and highest was obtained in sun dried ones. Maximum moisture was recorded in fresh fish while it decreased in all preserved fish. In case of ash content, it was least in fresh fishes and highest in sun dried fishes. Glucose and triglycerides also showed alterations with maximum glucose in fresh fish and highest triglycerides in sun dried fish. From this study it is suggested that fresh fishes maintained its maximum nutrient content, therefore they should be preferably consumed over preserved fishes.

Keywords: Nutritive Content; Preservation Method; Heteropneustes Fossilis

\section{Introduction}

Fish is considered as nutritionally valuable part of the human diet as it is a rich source of animal protein and omega 3 fatty acids [1]. They are 90\% digestible and constitute important part of food in poverty prone countries. It is also good source of Selenium, Vitamin D, Phosphorus and Calcium [2,3]. Many researchers have shown positive health effects of consuming fishes such as decreased risk of coronary heart and cardiovascular diseases, decreased inflammatory disease as arthritis and prevention of cancer as shown by many researchers $[4,5]$.

Due to high therapeutic and nutritional benefits, consumption of fish has gradually increased in the last decades. Growing human population in many countries 


\section{International Journal of Zoology and Animal Biology}

has also caused increased demand for fish food. To meet the ever-increasing demand for fish, aquaculture has expanded very rapidly and is now the fastest growing food producing industry in the world.

One of the major problems faced by the fisheries industries is spoilage of fish. In the tropical countries such as India, hot climate favours the rapid growth of bacteria which leads to spoilage of fishes and deterioration of its quality which in turn also decrease the capital gain [6].

According to Adesehinwa AOK, et al. [7] capture fish provides over $60 \%$ of total domestic production peranum. But it faces about $30-50 \%$ post-harvest losses due to spoilage of fishes. Hence fishes should be well preserved to maintain its quality and to avoid its spoilage.

Preservation techniques are required to prevent fish spoilage and increase shelf life [8]. They should be designed to inhibit the activity of spoilage bacteria and metabolic changes that result in the loss of fish quality. Spoilage bacteria produce unpleasant odor and flavor associated with spoiled fish.

Preservation should be done in such a manner that the fishes remain fresh for a long time, with minimum loss of flavor, test, odor, nutritive value and digestibility of their flesh.

There are many methods of fish preservation such as freezing, Oven drying, Sun drying etc [9]. Every preservation method has its own limitations and has different impact on nutritive value of fishes.

In present study we tried to evaluate the effect of different preservation methods such as Freezing, Oven drying, Sun drying on nutritive value of Heteropneustes fossilis preserved for 7 days and also tried to know which preservation method retains maximum nutritive value in fish. $H$. fossilis fish is very excellent in taste and have high market and medicinal value [10]. Due to its high nutritive value this fish is recommended in the diet of the sick and convalescent [11].

\section{Materials and Methods}

\section{Study Area}

The selected area of study was a local fish market Rasalganj, Aligarh city located in Uttar Pradesh, a north province of India. Aligarh city is located at the corrdinate $27.88^{\circ} \mathrm{N} 78.08^{\circ} \mathrm{E}$ in the middle portion of the daob, the land between Ganges and the Yamuna rivers.

\section{Sample Collection}

Irrespective of their age and sex, $H$. fossilis of approximately of same length and weight (weighing $25 \pm 2.30 \mathrm{gm}$ and with a length of $14 \pm 1.20 \mathrm{~cm}$ ) were purchased from a local fish market Rasalganj, Aligarh.

\section{Processing and Preservation of Fish Samples}

Freezing: Fresh samples of $H$. fossilis were collected and washed with tap water severally before rinsing with distilled water, then cut into slices. The slices were stored in a plastic container in a refrigerator. The fishes were frozen at a temperature of $-20^{\circ} \mathrm{C}$ for 7 days.

Sun drying: The collected fish samples were washed with tap water severally before rinsing with distilled water and then cut into slices. The slices were stored in a container and kept under sun for a period of 7 days.

Oven drying: The slices of fish were stored in a container in a hot oven at $40^{\circ} \mathrm{C}$ for 7 days.

Fresh Fish: Fresh fishes were not processed and dissected out just after purchasing from the market and analyses were done.

Chemical analysis: In the laboratory, the protein, lipid, moisture, ash, glucose and triglyceride content of the different preserved fish were estimated. For the samples of frozen, sun drying, oven drying and the fresh fish, the protein, lipid, moisture, ash, glucose and triglyceride contents were analysed using the different standard protocols.

Protein content: The protein content in different preserved fish samples were estimated by Lowry $\mathrm{OH}$, et al. [12].

Lipid content: The lipid content in fish samples after preservation were analysed by Folch JL, et al. [13] by extraction of lipid using chloroform and methanol.

Moisture determination: The samples were weighed first (Initial weight), and then dried in electric oven at $105^{\circ} \mathrm{C}$ for 24-30 hours to obtain a constant weight.

The moisture content was calculated as follows:

$$
\text { Moisture } \%=\frac{\text { initial weight }- \text { dry weight }}{\text { Initial weight }} \times 100
$$

\section{$>\quad$ Ash Determination}

Ash was determined by heating $1 \mathrm{~g}$ of samples from each preserved fish at $550 \mathrm{C}$ in a muffle furnace until a constant weight was obtained.

Ash percentage was calculated by the following formula: 


$$
\text { Ash } \%=\frac{\text { Ash weight }}{\text { Sample weight }} \times 100
$$

Glucose Estimation

Glucose content was estimated by GOD-POD, End Point Assay (AUTOSPAN) Kit.

\section{$>\quad$ Triglyceride Estimation}

Triglyceride was estimated by GPO-PAP, End Point Assay (AUTOSPAN) Kit.

Statistical Analysis: For statistical analysis, Student's ttest was performed to confirm the variability $(p<0.05)$ in the data obtained from fresh fish and preserved fishes.

\section{Results}

The effect of different preservative methods on nutritional contents such as protein, lipid, moisture, ash, glucose and triglycerides of $H$. fossilis has shown in figure 1-6.

The protein content was found to be significantly highest $(\mathrm{P}<0.05)$ in fresh fish $(22 \pm 0.44 \%)$, followed by frozen fish $(19.4 \pm 4.97 \%)$, sun dried fish $(14.18 \pm 4.59 \%)$ and oven dried fish $(12.2 \pm 7.61 \%)$ respectively (Figure 1 ).

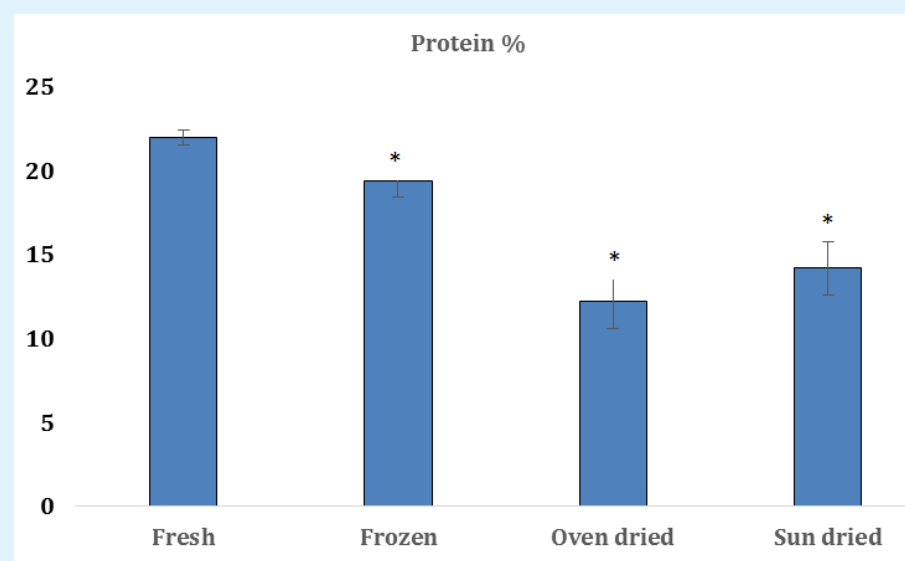

Figure 1: *Indicates significant difference $(\mathrm{P}<.05)$ in protein percentage of preserved fish from fresh fish.

Opposite trend was observed in case of lipid content. The highest lipid content was observed $(\mathrm{P}<0.05)$ in sun dried fish $(4.952 \pm 0.55 \%)$, followed by oven dried
(4.734 $\pm 0.61 \%)$, and frozen fish $(4.26 \pm 0.371 \%)$ and least was found fresh fish (2. $6 \pm 0.23 \%$ ) (Figure 2).

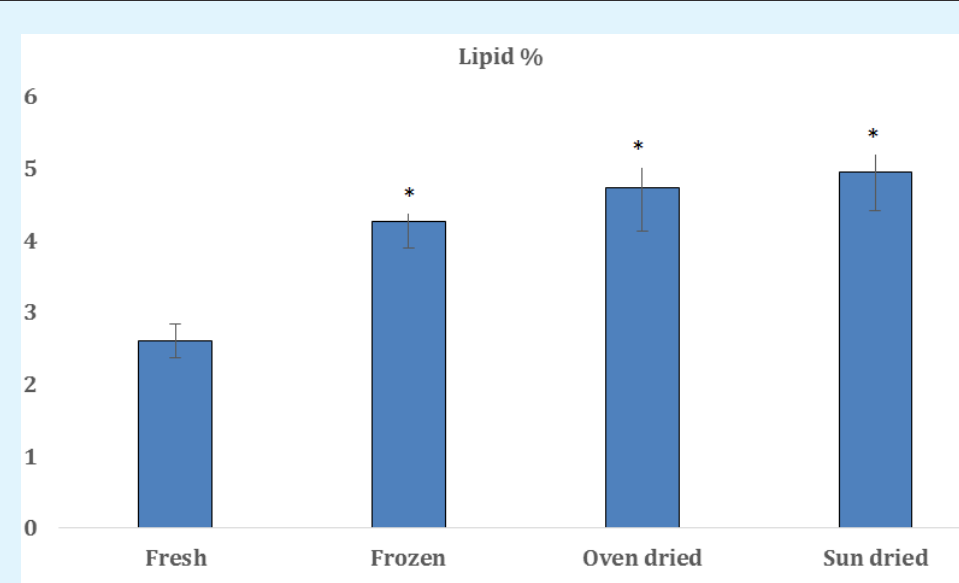

Figure 2: *Indicates significant difference $(\mathrm{P}<.05)$ in lipid percentage of preserved fish from fresh fish. 
The moisture content was found to be significantly highest $(\mathrm{P}<0.05)$ in fresh fish $(67.34 \pm 2.55 \%)$ in comparison to preserved fish and least was observed in sun dried fish $(3.99 \pm 0.23 \%)$. The moisture content in frozen fish and oven dried fish were $58.42 \pm 3.21 \%$ and $8.77 \pm 0.17 \%$ respectively (Figure 3 ).

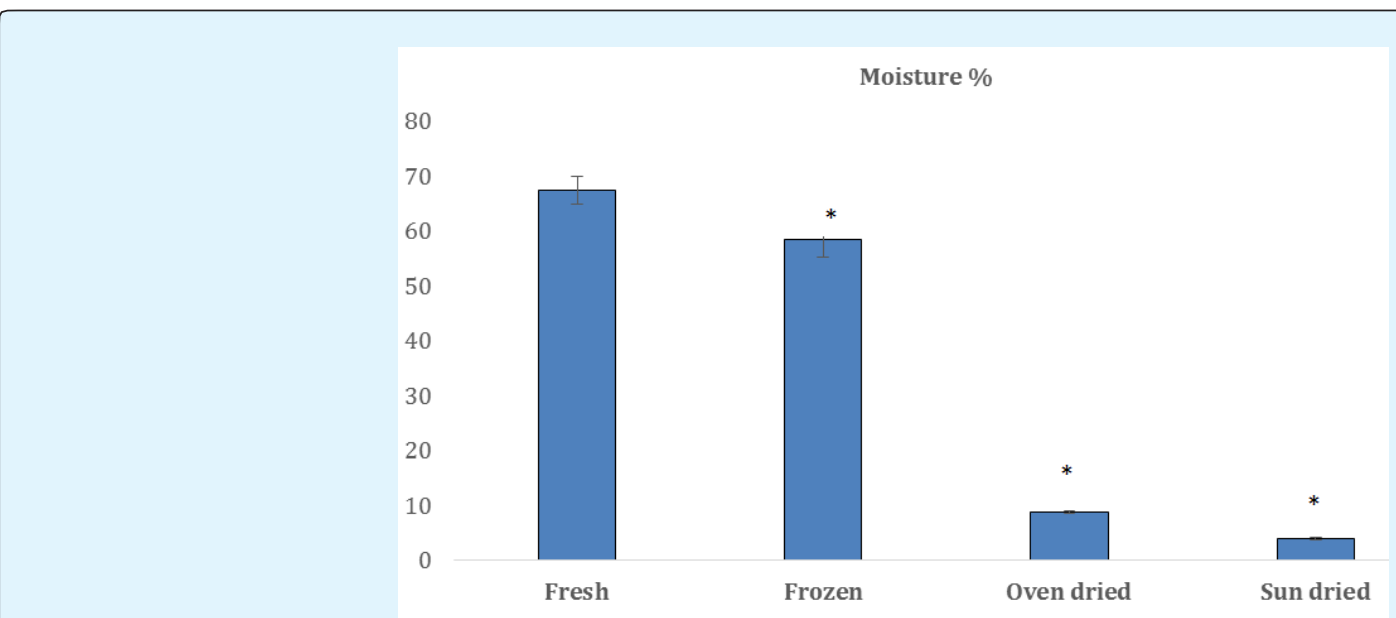

Figure 3: *Indicates significant difference $(\mathrm{P}<.05)$ in moisture percentage of preserved fish from fresh fish.

The least amount of ash content was noticed in fresh fish $(1 \pm 0.02 \%)$ while highest was observed in sun dried fish $(1.6 \pm 0.08 \%)$. Oven dried and frozen fish contained
$1.2 \pm 0.03 \%$ and $1.1 \pm 0.029 \%$ of ash content respectively (Figure 4).

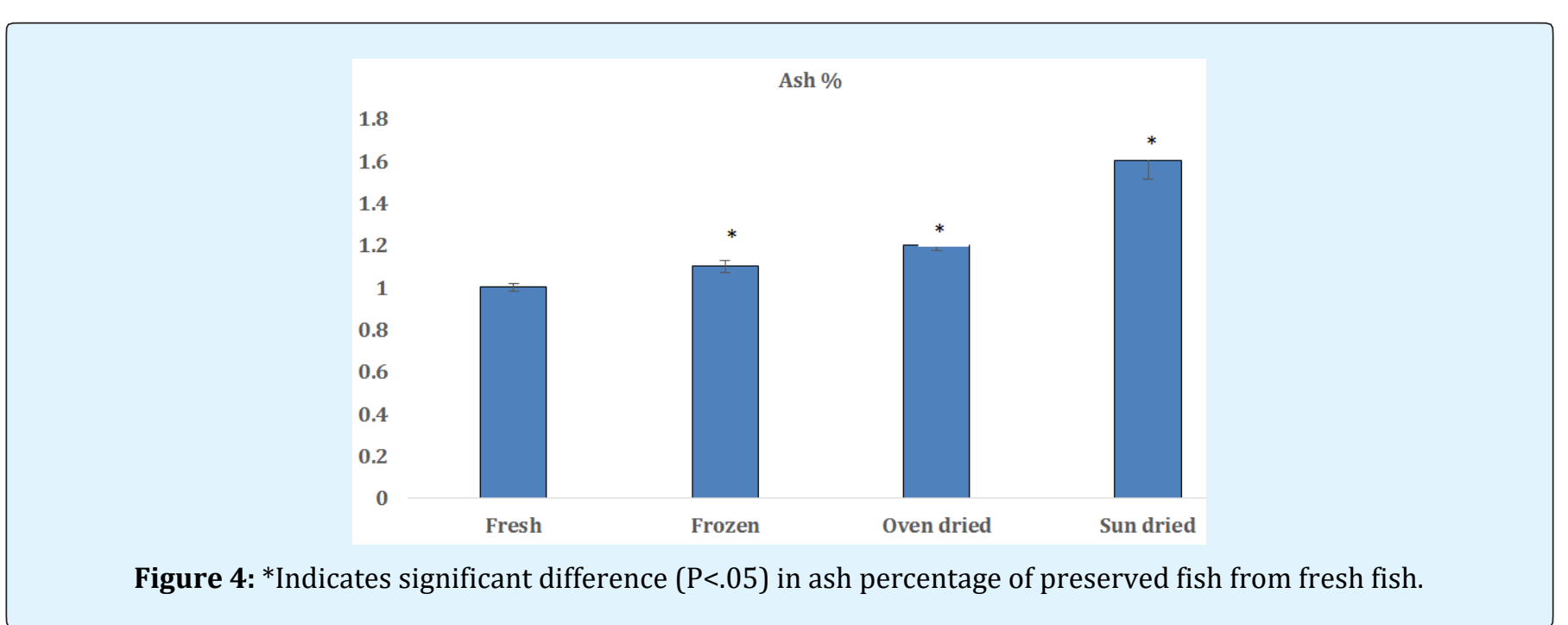

The significantly highest $(\mathrm{P}<0.05)$ amount of glucose was found in fresh fish $(16.08 \pm 0.32 \mathrm{mg} / \mathrm{gm})$, followed by sun dried fish $(15.20 \pm 0.40 \mathrm{mg} / \mathrm{gm})$, followed by oven dried fish $(14.56 \pm 0.29)$ and least was observed in frozen fish (12.2 \pm 0.68 ) (Figure 5). 


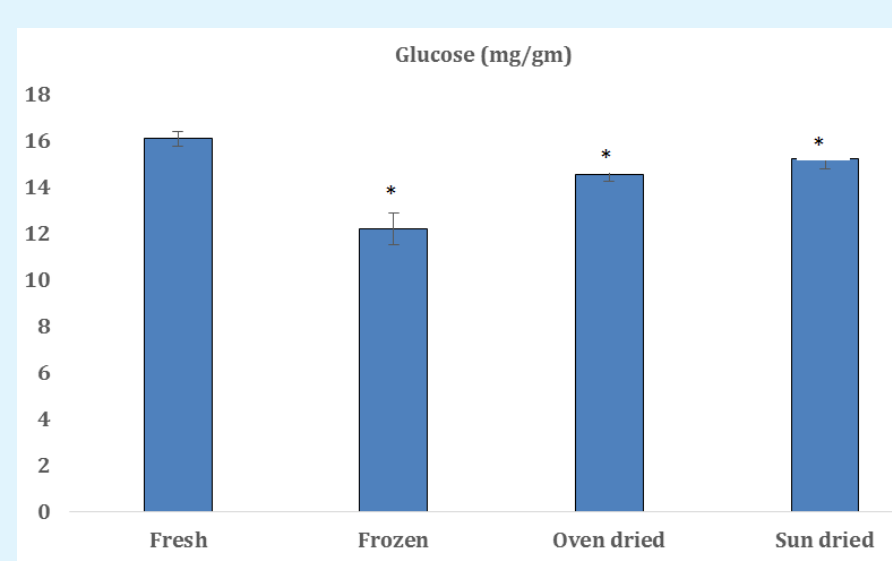

Figure 5: *Indicates significant difference $(\mathrm{P}<.05)$ in glucose content of preserved fish from fresh fish.

The triglyceride content was significantly highest $(\mathrm{P}<0.05)$ in sun dried fish $(22.97 \pm 1.27 \mathrm{mg} / \mathrm{gm})$ and least was in fresh samples (18.13 \pm 0.38$)$. The amount of triglyceride was found to be $21.08 \pm 0.55 \mathrm{mg} / \mathrm{gm}$ in frozen fish and $19.62 \pm 0.39 \mathrm{mg} / \mathrm{gm}$ in oven dried fish (Figure 6).

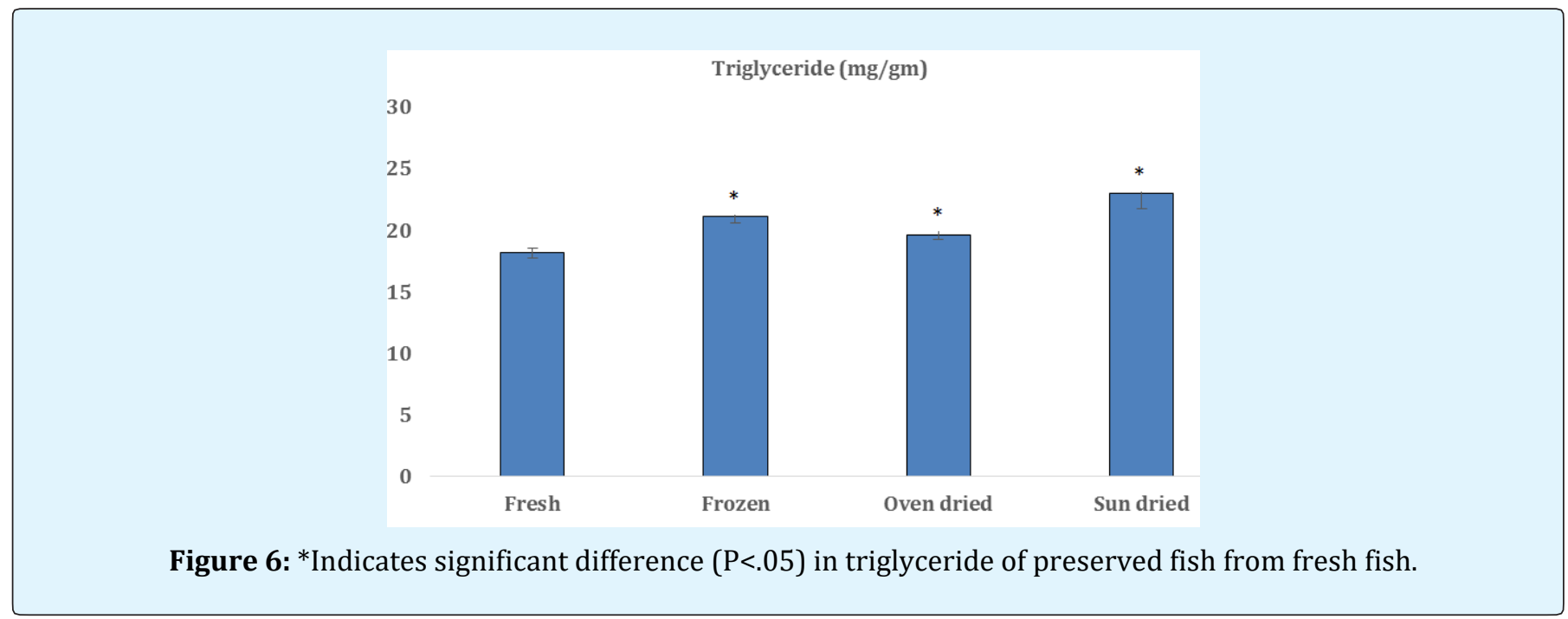

\section{Discussion}

Effect of different preservative methods on the nutritional content of $H$. fossilis in this study is in agreement with the report of Bassey FI, et al. [14] who reported that different preservative methods cause alteration in percentage of protein, lipid, moisture and ash content.

In present study protein was found to be lower in all samples after preservation (Figure 1). It might be as a result of denaturation of protein molecule after preservation. Oluwaniyi 00, et al. [15] has also observed the decrease protein content in fishes after preservation.

Lipid showed opposite trend to the changes in protein percentage as after preservation of fishes, lipid percentage gets increased after all preservation method than fresh fish (Figure 2). This is in contradiction with the studies of Roopma G, et al. [16] and Saliu JK, et al. [17] who observed decreased lipid content in fishes after preservation. 


\section{International Journal of Zoology and Animal Biology}

Moisture content was found to be decreased in all preserved fishes in comparison to fresh fishes (Figure 3). Ali Aberoumand A, et al. [18] has also noticed decreased moisture content in frozen fishes. Sun dried and oven dried method also caused decreased moisture content in fishes due to dehydration process.

Ash content was found to be higher in all preserved fish compare to fresh fish (Figure 4). Decrease in moisture content after preservation might be the reason for increased ash content [19].

Variation in glucose content was also observed in fishes after preservation. Decreased level of glucose was obtained in all preserved fishes when compared to fresh fishes (Figure 5).

Increased triglyceride content in all preserved fishes might be reason for increased triglyceride level in all fishes after preservation (Figure 6).

\section{Conclusion}

This study showed the effect of different preservative methods such as freezing, sun drying, and oven drying on the nutritional contents of $H$. fossilis in comparison to fresh fish. The protein, moisture and glucose contents were found to be higher in fresh fish than all the preserved fish. The least amount of lipid, triglycerides and ash was observed in fresh fish. The protein is the most important nutrient as it contains all the essential amino acids that builds the body and maintain body functions. Therefore, fresh fish should be more preferable for consumption compared to preserved fish.

\section{References}

1. Andrew AE (2001) Fish-processing Technology. University of Ilorin press, Nigeria pp: 8-17.

2. Mohanty BP, Mohanty A, Ganguly S, Mitra T, Karunakaran D, et al. (2017) Nutritional composition of food fishes and their importance in providing food and nutritional security, Food Chemitry 293: 561570 .

3. Bashir FA, Shuhaim Othman M, Mazlan AG (2012) Evaluation of trace metal levels in tissues of two commercial fish species in Kapar and Mersing coastal waters, Peninsular Malaysia. J Environ Public Health 2012: 10.
4. Dyerberg J (1986) Linolenate derived polyunsaturated fatty acids and prevention of atherosclerosis. Nutr Rev 44(4): 125-134.

5. Rudkowska I, Marcotte B, Pilon G, Lavigne C, Marette A, et al. (2010) Fish nutrients decrease expression levels of tumor necrosis factor-alpha in cultured human macrophages. Physiol Genomics 40(3): 189194.

6. Whittle KJ (1997) Opportunities for improving the quality of fisheries products. In: Adesehinwa AOK, Ayanda JO, Bolorunduro PI, et al. (Eds.), Adoption of improved fish preservation technologies in Northwestern Nigeria. Tropicultural 23: 117-123.

7. Adesehinwa AOK, Ayanda JO, Bolorunduro PI (2005) Adoption of improved fish preservation technologies in Northwestern Nigeria. Tropicultural 23: 117-123.

8. Ryder JM, Fletcher GC, Stec MG, Seelye RJ (1993) Sensory, Microbiological and chemical changes in hake stored in ice. International Journal of Food Science and Technology 28(2): 169-180.

9. Tairu HM, Adedokun MA, Adelodun OB, Badmus BD (2017) Microbial examination of some selected natural preservatives on the shelf Life and safety of smoked Tilapia fish (Oreochromis niloticus). Res Rev: J Microbiol Biotechnol 6(1): 28-35.

10. Talwar PK, Jhingran AG (1991) Inland Fishes of India and Adjacent Countries. Oxford-IBH Publishing Co. Pvt. Ltd., New Delhi pp: 1158.

11. Singh Kohli MP, Goswami UC (1989) Studies on age and growth of an air-breathing catfish Heteropneustesfossilis (Bloch). J Inland Fish Soc India 21(2): 17-24.

12. Lowry $\mathrm{OH}$, Rosenbrough NG, Farr AL, Randall RG (1951) Protein Measurements with Folin Phenol Reagent. J Biol Chem 193(1): 265-275.

13. Folch JL, Sloane Stanley GH (1957) A Simple Method for Isolation and Purification of Total Lipids from Animal Tissues. J Biol Chem 226(1): 497-509.

14. Bassey FI, Oguntunde FC, Chukwujindu M, Iwegbue A, Osabor VN, et al. (2013) Effects of processing on the proximate and metal contents in three fish species from Nigerian coastal waters. Food Sci Nutr 2(3): 272-281. 


\section{International Journal of Zoology and Animal Biology}

15. Oluwaniyi 00, Dosumu 00 (2009) Preliminary studies on the effect of processing methods on the quality of three commonly consumed marine fishes in Nigeria. Biokemistri 21(1): 1-7.

16. Roopma G, Meenakshi K, Sweta G, Shallini S (2012) Change in proximate composition and microbial count by low temperature preservation in fish muscle of Labeo rohita (Ham- Buch). J Pharm Biol Sci 2(1): 13-17.

17. Saliu JK (2008) Effect of Smoking and frozen storage on the nutrient composition of some African fishes. Adv Nat Appl Sci 2(1): 16-20.
18. Ali Aberoumand A (2014) Preliminary studies on nutritive and organoleptic properties in processed fish fillets obtained from Iran Food Science and Technology (Campinas) 34(2): 287-291.

19. Ahmed S, Rahman A, Mustafa G, Hussain B, Nahar N (2012) Nutrient composition of indigenous and exotic fishes of rainfed waterlogged paddy fields in Lakshmipur, Bangladesh. World Journal of Zoology 7(2): 135-140. 